\title{
Retraction Note: Fatal factitious Cushing syndrome (Münchhausen's syndrome) in a patient with macroprolactinoma and silent corticotrophinoma: case report and literature review
}

Carlos André Minanni ${ }^{1}$, Ana Luiza De Almeida Cardoso ${ }^{1}$, Edoarda Vasco de Albuquerque Albuquerque Luciana Pinto Brito ${ }^{2}$, Ludmilla Malveira Lima Lopes ${ }^{1}$, Andrea Glezer ${ }^{1}$, Elisa Del Rosario Ugarte Verduguez ${ }^{3}$, Berenice Bilharinho De Mendonça², Marcello Delano Bronstein ${ }^{1}$, Marcio Carlos Machado and Maria Candida Barisson Villares Fragoso ${ }^{1,4^{*}}$

The Publisher is retracting this case report and literature review [1] as the case has been previously published in the Journal of Women's Health Care [2] and is therefore a redundant publication.

\begin{abstract}
Author details
${ }^{1}$ Neuroendocrinology Unit, São Paulo, Brazil. ${ }^{2}$ Laboratory of Hormones and Molecular Genetics - LIM/42, São Paulo, Brazil. ${ }^{3}$ Division of Psychology, Adrenal Unit, São Paulo, Brazil. ${ }^{4}$ Hospital das Clinicas da Faculdade de Medicina, University of São Paulo, São Paulo, Brazil.

Received: 17 February 2016 Accepted: 17 February 2016

Published: 3 March 2016

\section{References}

1. Minanni CA, De Almeida Cardoso AL, de Albuquerque Albuquerque EV, Pinto Brito L, Lima Lopes LM, Glezer A, Del Rosario Ugarte Verduguez E, Bilharinho De Mendonça B, Bronstein MD, Machado MC, Fragoso MCBV. Fatal factitious Cushing syndrome (Münchhausen's syndrome) in a patient with macroprolactinoma and silent corticotrophinoma: case report and literature review. Clin Diabetes Endocrinol. 2015;1:3.

2. Minanni CA, Cardoso ALA, Albuquerque EVA, Lopes LML, Glezer A, Verduguez ERU, Gallucci-neto J, Gattaz WF, Mendonça BB, Bronstein MD, Machado MC, Fragoso MCBV. Fatal factitious Cushing's syndrome (Münchhausen's syndrome) in a patient with a prolactinoma and silent corticotrophinoma: case report and literature review. J Women's Health Care. 2014;3:162
\end{abstract}

\footnotetext{
* Correspondence: maria.villares@hc.fm.usp.br

The online version of the original article can be found under doi:10.1186/ s40842-015-0002-8.

${ }^{1}$ Neuroendocrinology Unit, São Paulo, Brazil

${ }^{4}$ Hospital das Clinicas da Faculdade de Medicina, University of São Paulo, São Paulo, Brazil

Full list of author information is available at the end of the article
}

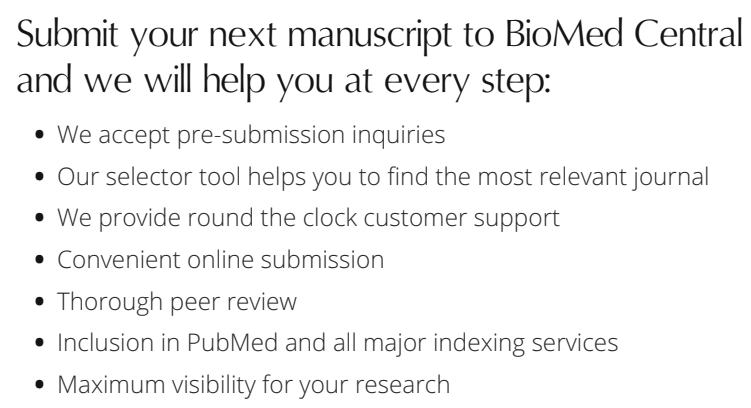

Submit your next manuscript to BioMed Central and we will help you at every step:

- We accept pre-submission inquiries

- Our selector tool helps you to find the most relevant journal

- We provide round the clock customer support

- Convenient online submission

- Thorough peer review

- Inclusion in PubMed and all major indexing services

- Maximum visibility for your research

Submit your manuscript at

www.biomedcentral.com/submit

BioMed Central 